\title{
Natural chemical control of marine associated microbial communities by sessile Antarctic invertebrates
}

\author{
Carlos Angulo-Preckler ${ }^{1,2, *}$, Eva García-Lopez ${ }^{3}$, Blanca Figuerola $^{4}$, Conxita Avila $^{1,2}$, \\ Cristina $\mathrm{Cid}^{3}$
}

\author{
${ }^{1}$ Department of Evolutionary Biology Ecology and Environmental Sciences, Faculty of Biology, University of Barcelona, \\ 08028 Barcelona, Catalonia, Spain \\ ${ }^{2}$ Biodiversity Research Institute (IrBIO), 08028 Barcelona, Catalonia, Spain \\ ${ }^{3}$ Microbial Evolution Laboratory, Center of Astrobiology (CSIC-INTA), 28850 Madrid Spain \\ ${ }^{4}$ Institute of Marine Sciences (ICM-CSIC), Pg. Marítim de la Barceloneta 37-49, 08003 Barcelona, Catalonia, Spain
}

\begin{abstract}
Organisms living in the sea are exposed to fouling by other organisms. Many benthic marine invertebrates, including sponges and bryozoans, contain natural products with antimicrobial properties, since microbes usually constitute the first stages of fouling. Extracts from 4 Antarctic sponges (Myxilla (Myxilla) mollis, Mycale tylotornota, Rossella nuda, and Anoxycalyx (Scolymastra) joubini) and 2 bryozoan species (Cornucopina pectogemma and Nematoflustra flagellata) were tested separately for antifouling properties in field experiments. The different crude extracts from these invertebrates were incorporated into a substratum gel at natural concentrations for an ecological approach. Treatments were tested by submerging plates covered by these substratum gels under water in situ during 1 lunar cycle $(28 \mathrm{~d})$ at Deception Island (South Shetland Islands, Antarctica). Remarkably, the butanolic extracts of M. tylotornota and C. pectogemma showed complete growth inhibition of microscopic eukaryotic organisms, one of the succession stages involved in biofouling. Our results suggest that different chemical strategies may exist to avoid fouling, although the role of chemical defenses is often species-specific. Thus, the high specificity of the microbial community attached to the coated plates seems to be modulated by the chemical cues of the crude extracts of the invertebrates tested.
\end{abstract}

KEY WORDS: Marine benthos · Porifera · Bryozoa · Bacteria · Eukaryotes · Antifouling Antimicrobial activity

\section{INTRODUCTION}

Submerged substrates are potentially exposed to a myriad of fouling organisms, and thus, competition is very intense and includes many chemically mediated interactions (Buss 1990, Steinberg \& De Nys 2002). The colonization of a substratum (biofouling) in the sea is a highly dynamic and complex process involving (1) adsorption on the new surface of dissolved organic molecules, forming a conditioning film, (2) colonization by bacteria with specific cell-surface, cell- cell, and interpopulation interactions shaping the structure, composition, and functions of surface-associated microbial communities (Dang \& Lovell 2016), (3) colonization by microscopic, unicellular eukaryotes, such as diatoms, fungi, and heterotrophic eukaryotes, and (4) settlement and growth of multicellular eukaryonts, such as invertebrate larvae and algal spores (Wahl 1997, Maki \& Mitchell 2002, Lema et al. 2019).

Several physicochemical properties (e.g. surface hydrophobicity, wetability, and/or surface molecular topography) may determine the adhesion of different 
bacterial species and microbial community assembly in the biofilms (Wiencek \& Fletcher 1997). Bacterial adhesion on submerged surfaces is a highly complex process, not only controlled by surface properties of the substrate, but also by surface properties of the bacterium itself (Harder \& Yee 2009).

Being sessile organisms, sponges and bryozoans rely mainly on bioactive compounds for defense against predators, competition for space, and overgrowth by fouling (Proksch et al. 2002). Moreover, their associated microorganisms (symbionts) may also be involved in chemical protection against fouling (Dobretsov et al. 2005, Ortlepp et al. 2008). Most invertebrates may remain relatively free from macrofouling while they often present some degree of microfouling (Richmond \& Seed 1991, Dobretsov et al. 2006).

From an ecological perspective, there are only a few reports which have analyzed the inhibition activity of organism extracts under field conditions. Only some of these studies were able to measure fouling settlement (Henrikson \& Pawlik 1995, 1998, AnguloPreckler et al. 2015, Dobretsov \& Rittschof 2020).

For Antarctic marine benthic organisms, very few studies have evaluated invertebrate antifouling defenses (Slattery et al. 1995, Angulo-Preckler et al. 2015, Patiño Cano et al. 2018). As mentioned above, potential colonization and overgrowth could be a potent selective pressure on marine benthic organisms, favoring the development of chemical defenses against fouling. Thus, it is ecologically relevant to perform in situ experiments to establish the activity of the organisms' extracts against environmental microorganisms under real environmental conditions. A field assay method for testing the antifouling activity of crude organic extracts of marine organisms was developed by Henrikson \& Pawlik (1995). Accordingly, the main advantages of this methodology are (1) the extract is incorporated into the medium simulating natural situations, where the products are located within the organism, (2) antifouling substances are liberated slowly, as presumably occurs in living organisms, and (3) the physical characteristics of the settlement surface remain unchanged (Henrikson \& Pawlik 1995).

This study aims to evaluate the potential antimicrofouling activity of sessile marine Antarctic invertebrates by comparing their crude extracts under real conditions. We hypothesize that these benthic invertebrates use chemical defense to regulate surfaceassociated microorganism colonization as an efficient way to control fouling pressure. Therefore, we used extracts (lipophilic and less hydrophobic extracts) from these invertebrates incorporated into artificial substrata that were submerged under in situ conditions. The biofilms (surface-associated communities developing on these substrata) were analyzed in terms of species composition and relative abundances (bacteria and eukaryotes) and used to infer the antifouling activity of each invertebrate species tested.

\section{MATERIALS AND METHODS}

\subsection{Sample collection and processing}

Sessile Antarctic invertebrate fauna from 2 common phyla (Porifera and Bryozoa) were selected to evaluate their potential antifouling activity. Four common species of sponges, 2 demosponges ( $\mathrm{MyX}_{\mathrm{X}}-$ illa (Myxilla) mollis Ridley \& Dendy, 1886, Mycale tylotornota Koltun, 1964), and 2 hexactinellids (Rossella nuda Topsent, 1901, Anoxycalyx (Scolymastra) joubini (Topsent, 1916)), together with 2 abundant bryozoan species (Cornucopina pectogemma (Goldstein, 1882), and Nematoflustra flagellata (Waters, 1904)), were selected for the experiment (Table 1). The sponges were collected in the Eastern Weddell Sea during the ANT/XXI-2 cruise of R/V 'Polarstern' (Alfred-Wegener-Institut), during the austral summer of 2003/2004, through bottom and Agassiz trawls. Bryozoans were collected by SCUBA diving in the vicinity of Livingston Island (South Shetland Islands) during the austral summer of 2012. A portion of each sample was conserved for further taxonomical identification at the University of Barcelona (UB). The remaining material was frozen at $-20^{\circ} \mathrm{C}$ until it was needed for the experiments.

Each organism was disaggregated into small pieces and ground with a mortar and a pestle homogenizing it in acetone to collect the crude extracts. Then, crude extracts were fractionated by polarity, separating the most polar compounds by extraction in butanol $(\mathrm{BuOH})$ from the less polar lipophilic compounds by extraction in diethyl ether $\left(\mathrm{Et}_{2} \mathrm{O}\right)$. The extraction procedure has been extensively described in previous works of our team (e.g. Avila et al. 2000). Natural concentrations of each extract compounds $\left(\mathrm{Et}_{2} \mathrm{O}\right.$ or $\mathrm{BuOH})$ were calculated as the total dry weight $\left(\mathrm{DW}_{\mathrm{T}}\right)$ of each sample $\left(\mathrm{DW}_{\mathrm{T}}=\right.$ dry weight of the solid residue + dry weight of the aqueous residue + dry weight of the $\mathrm{Et}_{2} \mathrm{O}$ extract + dry weight of the $\mathrm{BuOH}$ extract; see Table 1). Fractionating by polarity is important to determine which type of compounds are responsible for any activity. 
Table 1. Taxonomic data and sampling details of the invertebrates tested. SCUBA: autonomous dive; AGT: Agassiz trawl; BT: bottom trawl

\begin{tabular}{|c|c|c|c|c|c|c|c|c|}
\hline \multirow[t]{2}{*}{ Phyla } & \multirow[t]{2}{*}{ Treatment } & \multirow[t]{2}{*}{ Location } & \multirow{2}{*}{\multicolumn{2}{|c|}{\begin{tabular}{c}
\multicolumn{3}{c}{ Coordinates } \\
Latitude \\
$\begin{array}{cc}\left({ }^{\circ} \mathrm{S}\right) & \left({ }^{\circ} \mathrm{W}\right)\end{array}$
\end{tabular}}} & \multirow[t]{2}{*}{$\begin{array}{l}\text { Sample } \\
\text { gear }\end{array}$} & \multirow[t]{2}{*}{$\begin{array}{l}\text { Depth } \\
\text { (m) }\end{array}$} & \multicolumn{2}{|c|}{$\begin{array}{c}\text { Natural concentration } \\
\left(\mathrm{g} \mathrm{gDW}^{-1}\right)\end{array}$} \\
\hline & & & & & & & $\mathrm{Et}_{2} \mathrm{O}$ extract & $\mathrm{BuOH}$ extract \\
\hline- & Control & - & - & - & - & - & - & - \\
\hline Bryozoa & $\begin{array}{l}\text { Cornucopina pectogemma } \\
\text { (Goldstein, 1882) }\end{array}$ & Livingston Is. & 62.65 & 60.616 & SCUBA & 20 & 0.028 & 0.024 \\
\hline Bryozoa & $\begin{array}{l}\text { Nematoflustra flagellata } \\
\text { (Waters, 1904) }\end{array}$ & Livingston Is. & 62.65 & 60.616 & SCUBA & 20 & 0.0869 & 0.0298 \\
\hline Porifera & $\begin{array}{l}\text { Myxilla (Myxilla) mollis } \\
\text { Ridley \& Dendy, } 1886\end{array}$ & Weddell Sea & 71.327 & 13.949 & AGT & 848 & 0.1374 & 0.0445 \\
\hline Porifera & $\begin{array}{l}\text { Mycale tylotornota } \\
\text { Koltun, } 1964\end{array}$ & Weddell Sea & 70.953 & 10.564 & BT & 337 & 0.1381 & 0.0874 \\
\hline Porifera & $\begin{array}{l}\text { Rossella nuda } \\
\text { Topsent, } 1901\end{array}$ & Weddell Sea & 71.075 & 11.576 & BT & 309 & 0.0117 & 0.0094 \\
\hline Porifera & $\begin{array}{l}\text { Anoxycalyx (Scolymastra) joubini } \\
\text { (Topsent, 1916) }\end{array}$ & Weddell Sea & 71.075 & 11.576 & BT & 309 & 0.0412 & 0.0257 \\
\hline
\end{tabular}

\subsection{Experimental design}

Gels were prepared by dissolving $1.57 \mathrm{~g}$ of Phytagel $^{\mathrm{TM}}$ (Sigma Chemical) per $100 \mathrm{ml}$ distilled water and stirring for $10 \mathrm{~s}$. After heating until boiling, the gel was allowed to cool down before an aliquot of extract dissolved in $3 \mathrm{ml}$ solvent (ether or methanol) was added and shaken to obtain the treatments. Each treatment combined 1 species and 1 type of extract. The amount of tissue extracted was equivalent to the amount of gel prepared, so that each experimental dish would have a natural concentration of metabolites, reflecting that in the extracted organism (Angulo-Preckler et al. 2015).

Three replicates of each extract treatment were prepared, as well as 3 gel controls for both extracts that contained only $3 \mathrm{ml}$ of diethyl ether (control for $\mathrm{Et}_{2} \mathrm{O}$ extracts) or methanol (control for $\mathrm{BuOH}$ extracts), respectively. Extracts were diluted in Phytagel $^{\mathrm{TM}}$ and poured into Petri dishes, and the gel was then allowed to completely solidify. The solvents were fully evaporated before the assays were performed. The Petri dishes were placed on 3 acrylic plates and covered with a metallic grid to prevent removal by predators while under deployment (Angulo-Preckler et al. 2015). The plates with their substratum gels were placed in Whalers Bay $\left(62.99^{\circ} \mathrm{S}, 60.56^{\circ} \mathrm{W}\right)$, Deception Island (Antarctica) at about $20 \mathrm{~m}$ depth and were maintained underwater for a full lunar cycle in January 2013. Two small buoys were attached to each plate to avoid burial of the structures by sedimentation and to keep the plates perpendicular to the water flow (see Fig. S1 in the Supplement at www.int-res.com/articles/suppl/ a085p197_supp.pdf). Once removed from the water, the coatings of the plates with their attached microbial communities (Phytagel ${ }^{\mathrm{TM}}$ discs) were immediately frozen for further genetic analysis. The seawater temperature ranged from 0 to $2.0^{\circ} \mathrm{C}$ during January 2013.

\subsection{DNA extraction and PCR amplification}

In the home laboratory, the Phytagel ${ }^{\mathrm{TM}}$ discs were thawed (3 replicates of each extract treatment) and subsequently swabbed with sterile cotton buds for the collection of surface bacteria following our previously described protocol (Angulo-Preckler et al. 2015). The genomic DNA from each individual cotton bud was extracted using the MO BIO PowerWater DNA Isolation Kit (MO BIO Laboratories). Extraction procedures were identical for all samples. DNA concentrations were determined using a Nanodrop 2000p (Thermo Scientific ${ }^{\mathrm{TM}}$ ).

The enzyme Taq DNA polymerase and AccuPrime specific primers were used to amplify the $16 \mathrm{~S}$ (Bacteria/Archaea) and 18S rRNA (eukaryotes) genes (Table S1 in the Supplement). PCR was carried out under the following conditions for bacteria and archaea: a first step of $2 \mathrm{~min}$ of denaturation at $94^{\circ} \mathrm{C}$, 35 cycles of denaturation at $94^{\circ} \mathrm{C}$ for $30 \mathrm{~s}$, annealing at $48^{\circ} \mathrm{C}$ for $30 \mathrm{~s}$, and extension at $68^{\circ} \mathrm{C}$ for $1 \mathrm{~min}$, followed by $10 \mathrm{~min}$ extension at $72^{\circ} \mathrm{C}$. For eukaryotes, PCR was carried out under the following conditions: 33 cycles of denaturation at $94^{\circ} \mathrm{C}$ for $30 \mathrm{~s}$, annealing 
at $46^{\circ} \mathrm{C}$ for $30 \mathrm{~s}$, and extension at $72^{\circ} \mathrm{C}$ for $35 \mathrm{~s}$, preceded by 5 min denaturation at $94^{\circ} \mathrm{C}$ and followed by 7 min extension at $72^{\circ} \mathrm{C}$. PCR products were purified using the QIAquick PCR purification kit (Qiagen), obtaining pure DNA. The quality of DNA was assessed by $1 \%$ agarose gels. To control for false-positive PCR signals, 11 of MilliQ water was frozen, thawed, and subjected to the same DNA extraction procedure. The concentration of the samples was adjusted to between 10 and $25 \mathrm{ng} \mathrm{\mu l}^{-1}$. PCRs were carried out using the thermocyclers GeneAmp PCR System 9700 (Applied Biosystems) and Ptc 200 Peltier Thermal Cycler (MJ Research).

\subsection{Cloning, sequencing and phylogenetic analysis}

PCR-amplified DNA fragments were cloned using the TOPO ${ }^{\circledR} \mathrm{TA}$ Cloning ${ }^{\circledR}$ Kit (Invitrogen). The ligation product was introduced into competent cells of $E$. coli (Strain Machi1-T1) for transformation by heat shock. The cells were inoculated on LB agar with ampicillin $\left(100 \mu \mathrm{g} \mathrm{ml}^{-1}\right)$ and X-Gal $\left(50 \mu \mathrm{g} \mathrm{ml}^{-1}\right)$ and plates were incubated at $37^{\circ} \mathrm{C}$ for $24 \mathrm{~h}$. White colonies were selected, inoculated on plates containing TB (terrific broth) and ampicillin and incubated at $37^{\circ} \mathrm{C}$ for $18 \mathrm{~h}$. The pellets obtained were used to extract the plasmid DNA with the fluid handling epMotion 5075 Vac robot (Eppendorf AG). Samples were then sequenced using a 48 capillary sequencer ABI 3730 XL (Applied Biosystems). Read-lengths of up to approximately $1000 \mathrm{bp}$ were achieved. A total of 900 bacterial and 900 eukaryotic clones were sequenced. Sequences were analyzed with UCHIME, to identify and remove chimeric reads, and classified to eliminate those that could be considered contaminants (Edgar et al. 2011). Operational taxonomic units (OTUs) were identified using BLAST at the NCBI database (http://ncbi.nlm.nih.gov/BLAST). Representative sequences were aligned using Clustal X 2.0 (Larkin et al. 2007).

Sequences obtained in this study were deposited in the National Center for Biotechnology Information (NCBI) sequence database under the accession numbers KX214587-KX214606 for Bacteria, and KX232671-KX232675 for eukaryotes. No sequences were obtained for Archaea.

Phylogenetic trees were obtained using MEGA version X (Kumar et al. 2018) with parsimony, neighborjoining, and maximum likelihood analyses. In all cases, general tree topology and clusters were stable, and reliability of the tree topologies was confirmed by bootstrap analysis using 1000 replicate alignments.
Analytic Rarefaction 1.3 software (https://strata.uga. edu/software) was used to calculate rarefaction curves (Fig. S2 in the Supplement). It revealed that rarefaction curves reached saturation at $3 \%$ sequence divergence, indicating that the samples contained almost all the diversity at this genetic distance.

\subsection{Statistical analysis}

The mean total number of clones (bacteria and eukaryotes) was determined from the 3 replicates of each treatment. The data were 4 root-transformed to achieve normality and homoscedasticity (Shapiro \& Wilk 1965). A 2-way factorial ANOVA block design (treatment [T] as a fixed effect factor and plate [P] as a random effect factor) was run to test for global significant differences between treatments (control and extracts were analyzed separately by polarity). No significant interactions for $\mathrm{T} \times \mathrm{P}$ were found and thus the data were reanalyzed running a 1-way ANOVA for each extract $\left(\mathrm{Et}_{2} \mathrm{O}\right.$ and $\left.\mathrm{BuOH}\right)$. Dunnett's post hoc tests were performed to determine which treatments showed differences from the controls.

Data from genetic analysis were used to build a matrix composed for clones grouped by phylotypes (OTUs). A dissimilarity matrix between samples was calculated using the Bray-Curtis distance after relative abundance data had been 4 square root transformed. A 3-way permutational multivariate analysis of variance (PERMANOVA; Anderson 2005) was used to test for any significant differences within and between factors. The PERMANOVA (unrestricted permutation of raw data method, using Monte Carlo test for testing pairwise differences between treatments) was run on a Bray-Curtis dissimilarity matrix with the PRIMER 6 + PERMANOVA software package (Plymouth Marine Laboratory). Effect sizes were calculated using the partial omega squared index $\left(\omega^{2} \mathrm{p}\right.$, Olejnik \& Algina 2003). A non-metric multidimensional scaling (NMDS) was also used to represent the results (Kruskal 1964). Furthermore, those data were used to calculate biodiversity indices for each treatment (number of taxa, OTU richness $S$, relative abundance N, and Shannon diversity index $H^{\prime}$ ). The microbial community was evaluated altogether, as well as bacteria and eukaryotes separately (see Table 2).

\section{RESULTS}

The number of Bacteria and Eukarya clones retrieved from the plates after $28 \mathrm{~d}$ of in situ incubation 

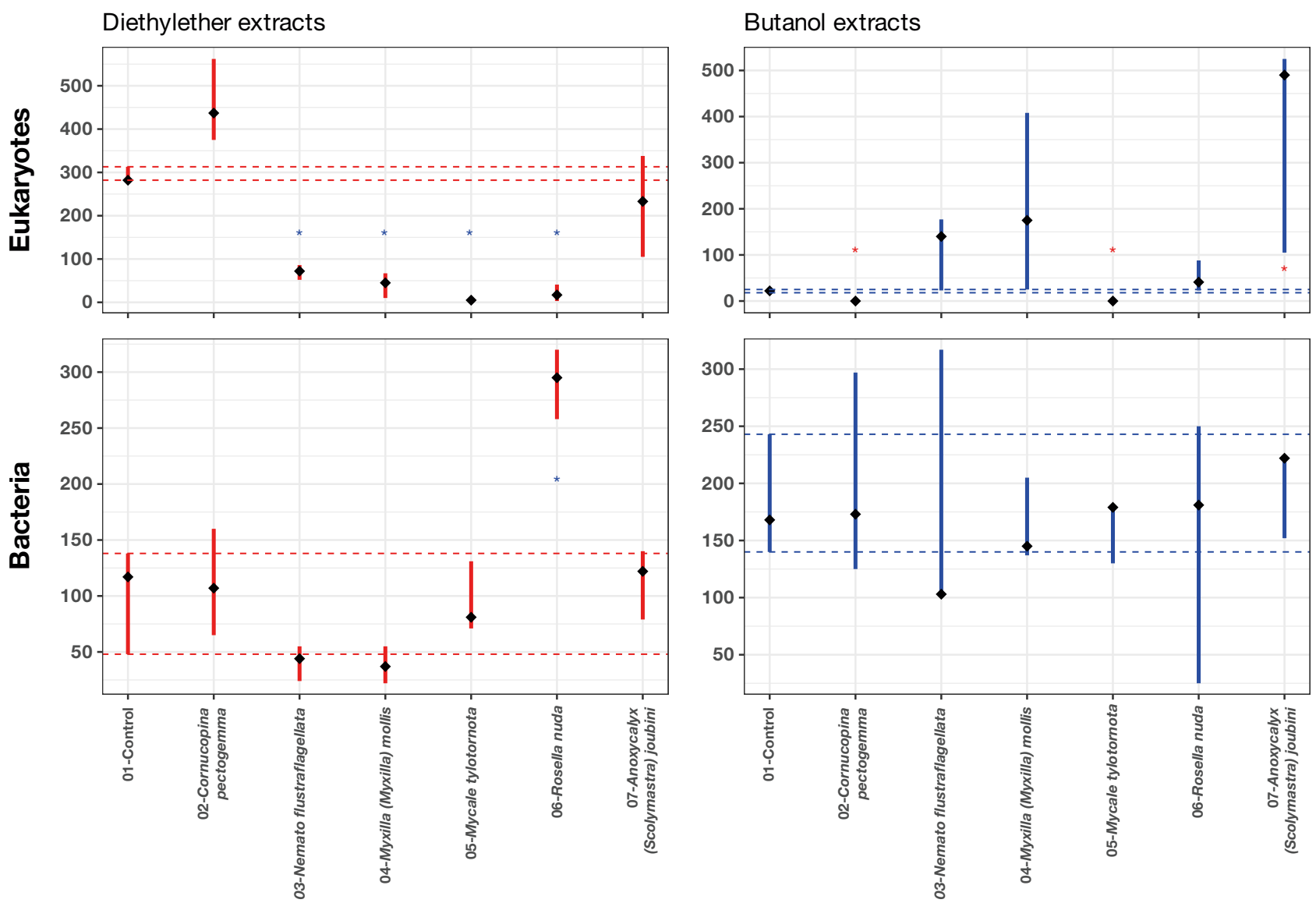

Fig. 1. Number of clones retrieved from plates per treatment. Eukaryotes and bacteria, showing results for the incorporation of diethyl ether $\left(\mathrm{Et}_{2} \mathrm{O}\right.$, red) and butanol $(\mathrm{BuOH}$, blue) extracts. Dashed lines show the values of the control treatments. ${ }^{*}$ Significantly different from control treatments $(\mathrm{p}<0.05)$. Error bars are SD

are shown for the different treatments (species extracted and control), prepared with their lipophilic diethyl ether and less hydrophobic butanol extracts (Fig. 1). On our plates, the number of unique OTUs was high. Furthermore, no diatoms were detected on our plates using $18 \mathrm{~S}$ cloning and sequencing.

\subsection{Number of clones}

Differences in the number of clones between experimental treatments and controls, determined by 1-way ANOVA with treatment as a fixed factor (Fig. 1), indicated that 3 out of 4 tests performed showed significant differences, i.e. bacteria on $\mathrm{Et}_{2} \mathrm{O}$ extracts $(\mathrm{p}=0.00005)$, eukaryotes on $\mathrm{Et}_{2} \mathrm{O}$ extracts $(\mathrm{p}=0.00005)$, and eukaryotes on $\mathrm{BuOH}$ extracts; $(\mathrm{p}=$ 0.0153), while bacteria on BuOH extracts ( $p=0.9825)$ showed no differences. Differences between the numbers of clones in the controls were also observed.
The $\mathrm{BuOH}$ extracts of the bryozoan Cornucopina pectogemma and the sponge Mycale tylotornota completely inhibited the growth of eukaryotic clones. On the other hand, 2 extracts significantly increased the number of clones settled on the gels with respect to the pertinent control treatments. Both extracts belong to hexactinellid sponges, but while the $\mathrm{Et}_{2} \mathrm{O}$ extract of Rosella nuda showed an increase in the abundance of bacterial clones, the $\mathrm{BuOH}$ extract of Anoxycalyx (Scolymastra) joubini showed an increase in the settlement of eukaryotic clones. In contrast with the antifouling activity showed by several extracts, the $\mathrm{Et}_{2} \mathrm{O}$ extract of $C$. pectogemma and the $\mathrm{BuOH}$ extract of Nematoflustra flagellata and Myxilla mollis favored the settlement of eukaryotic clones. The data showed significant differences in the $\mathrm{Et}_{2} \mathrm{O}$ extracts with an opposite trend: a large decrease in the abundance of eukaryotic clones together with the highest abundance of bacterial clones. 


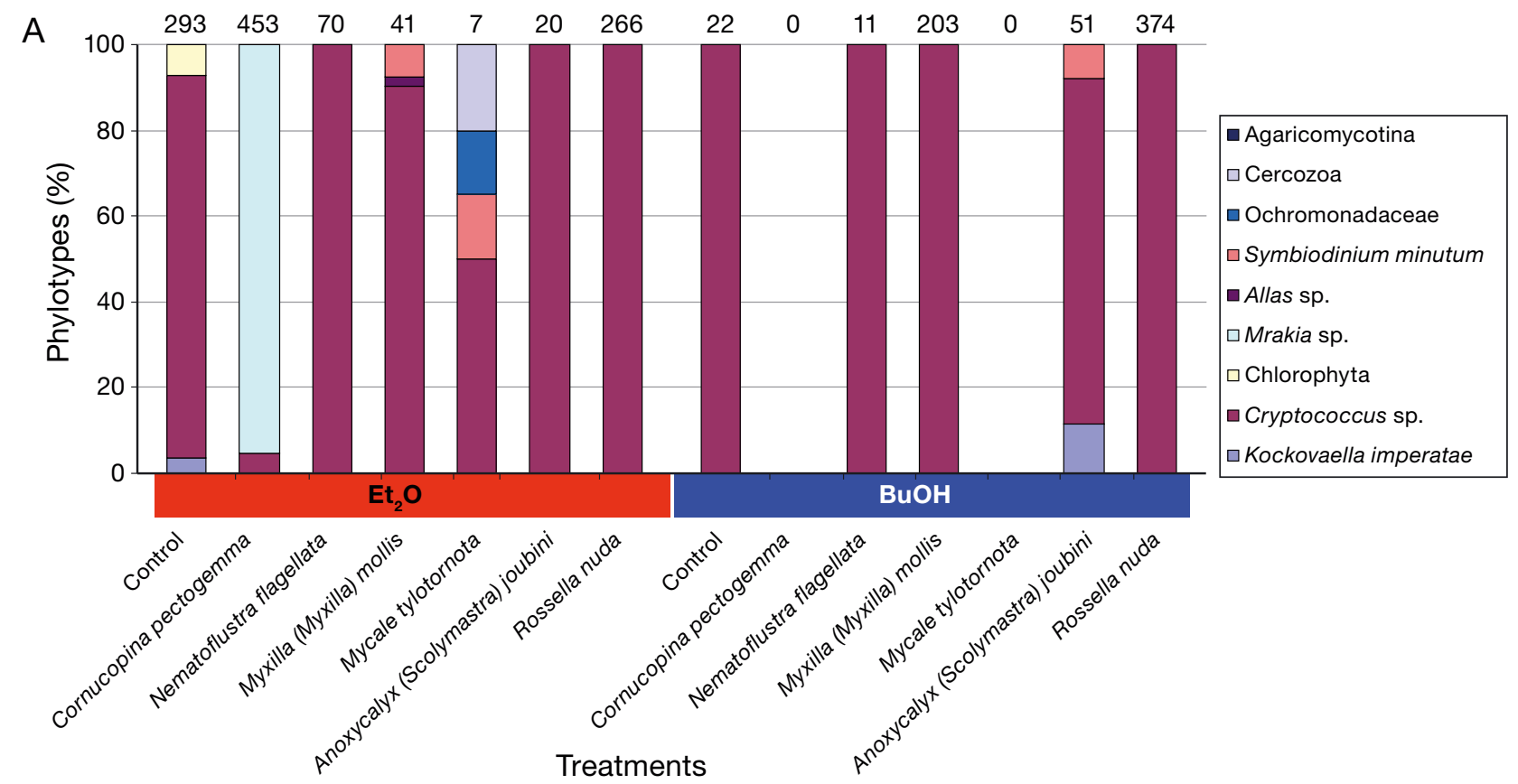

B

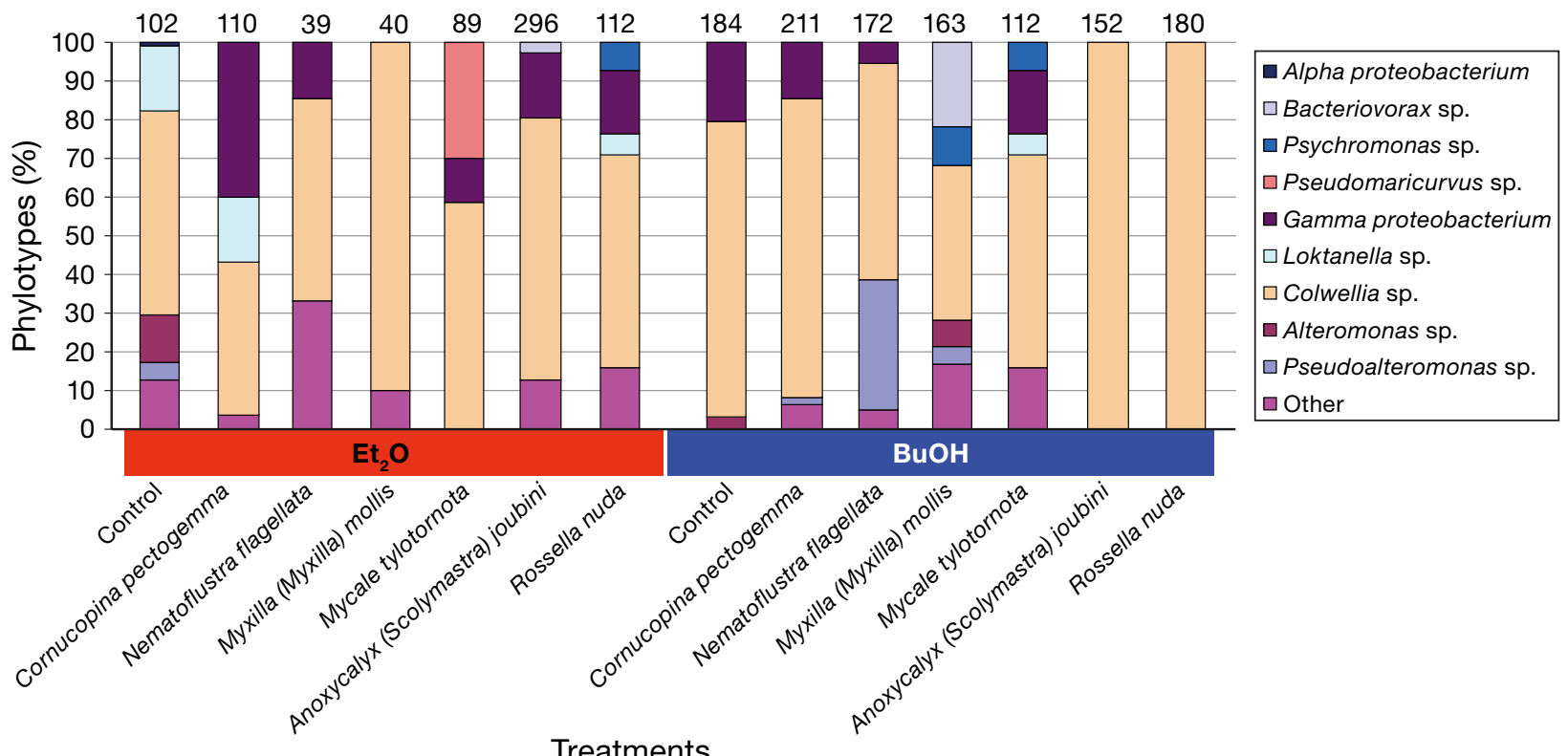

Treatments

Fig. 2. Microbial community composition in the biofilms growing on the plates for the different treatments. (A) Eukaryotic communities; (B) Bacterial communities. Numbers above columns indicate clone abundance by fraction-extract

\subsection{Microbial community composition}

For each treatment, all 3 replicates showed very similar microorganism communities (Fig. 2), and highly specific bacterial assemblage. A total of 850 bacterial clones were isolated, divided into: 770 Gammaproteobacteria (90.6\%), 54 Alphaproteobacteria $(6.4 \%), 19$ Deltaproteobacteria $(2.2 \%), 4$ Actinobacteria $(0.5 \%)$, and 3 Bacteroidetes $(0.4 \%)$. Phylogenetic diversity of $16 \mathrm{~S}$ rRNA gene clones revealed
28 bacterial phylotypes distributed mainly among the Gammaproteobacteria and Alphaproteobacteria (with Colwellia sp. and Loktanella sp. as the most abundant related genera, with 544 and 24 clones, respectively), The most abundant bacterial groups were related to Colwellia sp. and Pseudoalteromonas sp. (64\% and $3.8 \%$, respectively) both belonging to Gammaproteobacteria, while Loktanella sp. was the most abundant Alphaproteobacteria phylotype (2.8\%) (see Table A1 in Appendix). 
Table 2. Diversity of microbial communities. $S$ : number of identified OTUs; N: total number of identified clones; $H^{\prime}$ : Shannon diversity index. Results are shown for total community divided by polarity, and separately for bacteria and eukaryotes

\begin{tabular}{|c|c|c|c|c|c|c|c|c|c|c|}
\hline \multirow[t]{2}{*}{ Treatment } & \multirow[t]{2}{*}{ Extract } & \multicolumn{3}{|c|}{ Eukaryotes } & \multicolumn{3}{|c|}{ Bacteria } & \multicolumn{3}{|c|}{ Total } \\
\hline & & $S$ & $\mathrm{~N}$ & $H^{\prime}$ & $S$ & $\mathrm{~N}$ & $H^{\prime}$ & $S$ & $\mathrm{~N}$ & $H^{\prime}$ \\
\hline Control & $\mathrm{Et}_{2} \mathrm{O}$ & 3 & 293 & 0.41 & 7 & 101 & 1.52 & 10 & 395 & 1.26 \\
\hline Cornucopina pectogemma & $\mathrm{Et}_{2} \mathrm{O}$ & 2 & 453 & 0.19 & 5 & 108 & 1.18 & 7 & 562 & 0.87 \\
\hline Nematoflustra flagellata & $\mathrm{Et}_{2} \mathrm{O}$ & 1 & 70 & 0 & 6 & 39 & 1.43 & 7 & 109 & 1.17 \\
\hline Myxilla (Myxilla) mollis & $\mathrm{Et}_{2} \mathrm{O}$ & 3 & 41 & 0.38 & 2 & 40 & 0.32 & 5 & 81 & 1.04 \\
\hline Mycale tylotornota & $\mathrm{Et}_{2} \mathrm{O}$ & 4 & 7 & 1.24 & 4 & 94 & 1.08 & 8 & 101 & 1.33 \\
\hline Rossella nuda & $\mathrm{Et}_{2} \mathrm{O}$ & 1 & 20 & 0 & 6 & 295 & 1.06 & 7 & 315 & 1.23 \\
\hline Anoxycalyx (Scolymastra) joubini & $\mathrm{Et}_{2} \mathrm{O}$ & 1 & 226 & 0 & 7 & 112 & 1.44 & 8 & 338 & 1.11 \\
\hline Control & $\mathrm{BuOH}$ & 1 & 22 & 0 & 3 & 184 & 0.64 & 4 & 206 & 0.91 \\
\hline Cornucopina pectogemma & $\mathrm{BuOH}$ & 0 & 0 & 0 & 4 & 198 & 0.73 & 4 & 198 & 0.73 \\
\hline Nematoflustra flagellata & $\mathrm{BuOH}$ & 1 & 113 & 0 & 5 & 173 & 1.04 & 6 & 286 & 1.30 \\
\hline Myxilla (Myxilla) mollis & $\mathrm{BuOH}$ & 1 & 203 & 0 & 5 & 163 & 0.83 & 6 & 366 & 1.06 \\
\hline Mycale tylotornota & $\mathrm{BuOH}$ & 0 & 0 & 0 & 8 & 163 & 1.72 & 8 & 163 & 1.72 \\
\hline Rossella nuda & $\mathrm{BuOH}$ & 3 & 51 & 0.62 & 1 & 152 & 0. & 4 & 203 & 0.72 \\
\hline Anoxycalyx (Scolymastra) joubini & $\mathrm{BuOH}$ & 1 & 374 & 0 & 2 & 201 & 0.33 & 3 & 575 & 0.76 \\
\hline
\end{tabular}

Moreover, 713 eukaryote clones were isolated, divided into: 690 Basidiomycetes (96.8\%), 11 Cercozoan $(1.5 \%), 8$ Dinoflagellata $(1.1 \%)$, and 4 Ochrophyta $(0.6 \%)$. Phylogenetic diversity of $18 \mathrm{~S}$ rRNA showed 9 eukaryote phylotypes, strongly dominated by Basidyomicota (Cryptococcus sp. with 584 clones, $81.9 \%$; followed by Mrakia sp. with 63 clones, 8.8\%) (see Table A2 in Appendix).

As many as 22 OTUs were found in only 1 treatment (in 1, 2, or 3 replicates but restricted to the same treatment). The highest richness and diversity of microorganisms was found for both extracts of the sponge Mycale tylotornota, while the lowest diversity and richness were found on both extracts of the bryozoan Cornucopina pectogemma (see Table 2). Surprisingly, the highest values of bacterial diversity was found on BuOH extracts of $M$. tylotornota, which were also found to have the lowest richness and diversity for eukaryotic clones (Fig. 2). In general, a

Table 3. Three-way PERMANOVA test. Factors: Species $(\mathrm{Sp})$, Plate $(\mathrm{Pl})$, and Extract $(\mathrm{Fr}) ; \omega^{2} \mathrm{p}$ : partial 'effect size' of each term; asterisks indicate significant difference

\begin{tabular}{|lcccccr|}
\hline Source & df & SS & MS & Pseudo- $F$ & p $($ perm $)$ & $\omega^{2} \mathrm{p}$ \\
\hline Species & 6 & 27146 & 4524.3 & 11.904 & $0.0001^{*}$ & 0.51 \\
Plate & 2 & 15.038 & 7.5191 & $1.39 \times 10^{-2}$ & 1 & -0.05 \\
Extract & 1 & 6256.3 & 6256.3 & 13.97 & 0.1 & 0.20 \\
Sp $\times \mathrm{Pl}$ & 12 & 4560.7 & 380.06 & 0.70408 & 0.9585 & -0.09 \\
Sp $\times \mathrm{Fr}$ & 6 & 26616 & 4436.1 & 8.218 & $0.0001^{*}$ & 0.51 \\
Pl×Fr & 2 & 895.7 & 447.85 & 0.82966 & 0.6584 & -0.01 \\
Res & 12 & 6477.6 & 539.8 & & & \\
Total & 41 & 71967 & & & & \\
\hline
\end{tabular}

wide variability was observed within the different extracts tested, in both bacteria and eukaryotic communities. The differences in the microbial community composition showed contrasting patterns depending on the extract polarity. PERMANOVA analysis showed significant differences in the Species ( $\mathrm{Sp}$ ) factor and in the interaction between Species and Extract $(\mathrm{Sp} \times \mathrm{Fr})$. Both showed the largest effect size (see Table 3), while the factors Plate and Extract showed no significant differences ( $p>0.05)$. PERMANOVA results show that differences among treatments were the largest component of variability, with effect sizes $\left(\omega^{2} p\right)$ of 0.78 and 0.75 for the $E t_{2} \mathrm{O}$ and $\mathrm{BuOH}$ extracts, respectively (Table 4). The global microbial community (bacteria and eukaryotes) was completely different in all $\mathrm{Et}_{2} \mathrm{O}$ extracts, while only Myxilla mollis was significantly different in the BuOH extracts (Table 5).

\section{DISCUSSION}

\subsection{Chemical control}

Our results suggest that the Antarctic benthic invertebrates tested here could chemically control their associated microbial communities. Microbial settlement depends on the composition of the bacterial biofilms, and the production or absence of certain proteolytic enzymes (Qian et al. 2007, Almeida \& Vasconcelos 2015). The high specificity of the microbial community attached to our coated plates seems to be modulated by the chemical cues of the extracts, with species identity being much more important 


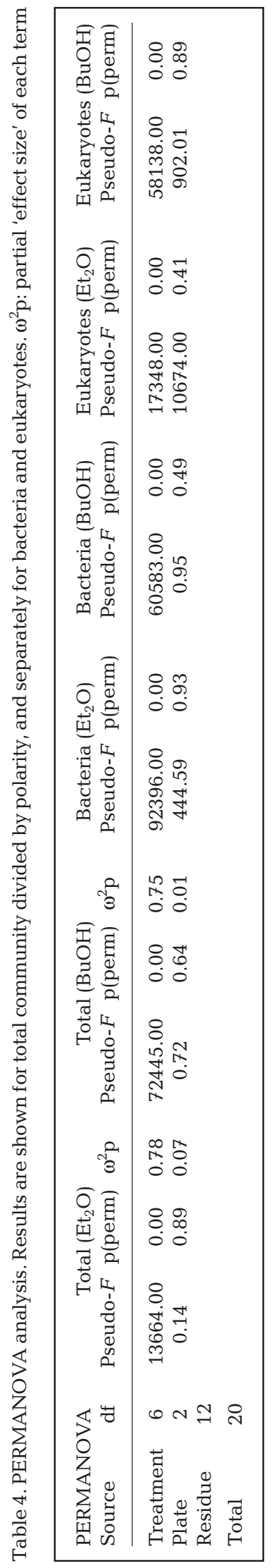

Table 5. Pairwise comparison of all treatments with controls using Dunnett's tests. Results are shown for total community, divided by polarity, and separately for bacteria and eukaryotes. CP: Cornucopina pectogemma; NF: Nematoflustra flagellata; MM: Myxilla mollis; MT: Mycale tylotornota; RN: Rossella nuda; AJ: Anoxycalyx joubini; nt: not tested; ${ }^{*}$ significant difference; $\mathrm{p}(\mathrm{MC})$ by Monte Carlo test

\begin{tabular}{|c|c|c|c|c|c|}
\hline Groups & $t$ & $\mathrm{p}(\mathrm{MC})$ & Groups & $t$ & $\mathrm{p}(\mathrm{MC})$ \\
\hline \multicolumn{3}{|l|}{ Total $\left(\mathrm{Et}_{2} \mathrm{O}\right)$} & \multicolumn{3}{|l|}{ Total (BuOH) } \\
\hline Control, CP & 3.71 & $0.0338^{*}$ & Control, CP & 14.941 & 0.2302 \\
\hline Control, NF & 39.046 & $0.0248^{*}$ & Control, NF & 30.013 & 0.051 \\
\hline Control, MM & 74.885 & $0.0083^{*}$ & Control, MM & 42.709 & $0.0236^{*}$ \\
\hline Control, MT & 17.702 & $0.0021^{*}$ & Control, MT & 26.024 & 0.0775 \\
\hline Control, RN & 3.983 & $0.0257^{*}$ & Control, RN & 25.341 & 0.076 \\
\hline Control, AJ & 34.959 & $0.0303^{*}$ & Control, AJ & 25.008 & 0.0732 \\
\hline \multicolumn{3}{|l|}{ Bacteria $\left(\mathrm{Et}_{2} \mathrm{O}\right)$} & \multicolumn{3}{|c|}{ Bacteria (BuOH) } \\
\hline Control, CP & 20.889 & 0.1167 & Control, CP & 13.014 & 0.2526 \\
\hline Control, NF & 44.007 & $0.0013^{*}$ & Control, NF & 25.168 & $0.0347^{*}$ \\
\hline Control, MM & 6.629 & $0.0009^{*}$ & Control, MM & 43.466 & $0.0035^{*}$ \\
\hline Control, MT & 57.457 & $0.0023^{*}$ & Control, MT & 22.397 & $0.0493^{*}$ \\
\hline Control, RN & 38.158 & $0.004^{*}$ & Control, RN & 21.639 & 0.0526 \\
\hline Control, AJ & 44.309 & $0.0034^{*}$ & Control, AJ & 19.298 & 0.0787 \\
\hline \multicolumn{3}{|c|}{ Eukaryotes $\left(\mathrm{Et}_{2} \mathrm{O}\right)$} & \multicolumn{3}{|c|}{ Eukaryotes (BuOH) } \\
\hline Control, CP & 67.272 & $0.0075^{*}$ & Control, CP & nt & nt \\
\hline Control, NF & 38.308 & $0.0281^{*}$ & Control, NF & 20.409 & 0.1151 \\
\hline Control, MM & 37.395 & $0.0224^{*}$ & Control, MM & 20.436 & 0.1036 \\
\hline Control, MT & 42.015 & $0.0194^{*}$ & Control, MT & nt & nt \\
\hline Control, RN & 3.945 & $0.0247^{*}$ & Control, RN & 4.11 & $0.0065^{*}$ \\
\hline Control, AJ & 25.323 & 0.0867 & Control, AJ & 47.157 & $0.0091^{*}$ \\
\hline
\end{tabular}

than the other factors evaluated (depth, phyla, extract; see Table 3, Fig. 3). Thus, the colonization of invertebrate surfaces may be induced and/or inhibited by the natural products present in the surface tissues or excreted by them. Our 18S rRNA gene sequencing, however, failed to detect diatoms, despite their common abundance in Antarctic waters. In a previous study, Toupoint et al. (2012) also failed to detect diatoms. This may be an artefact due to the primers used; diatoms are not commonly retrieved from environmental clone libraries, except when they occur in high abundance (Potvin \& Lovejoy 2009, Briand et al. 2018). Alternatively, diatoms may really not have been present after $28 \mathrm{~d}$, which could be too short a period for their settlement and growth in the biofilms. Although 1 mo has been considered to be long enough to achieve a relative stability and maturation in multispecies biofilms (Dang et al. 2008), this may take longer in Antarctic waters. It is important to recognize, however, that the methodology used here only reflects the number of different $16 \mathrm{~S}$ rRNA and 18S rRNA genes retrieved from a sample, which may not reflect the numbers of different organisms originally in the sample. Any assay evaluating this has constraints when trying to reflect natural conditions (Angulo-Preckler et al. 2015). Furthermore, it is also necessary that the putative active chemicals are present in large enough concentrations to have a significant biological effect, in order to demonstrate that naturally produced chemicals mediate in a given biological interaction. Although both solvents were completely evap- 

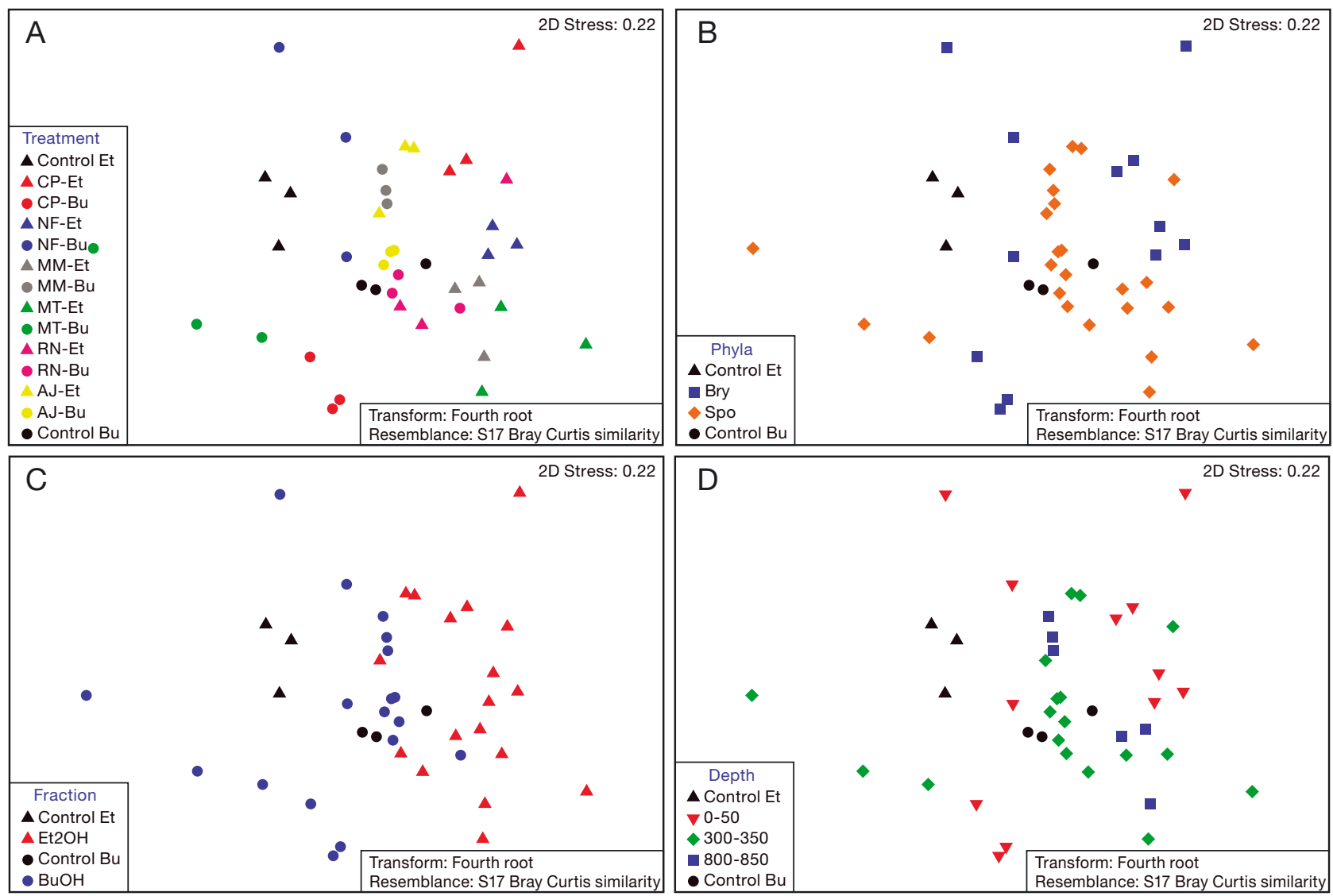

Fig. 3. Non-metric multidimensional scaling of treatment, phyla, extract and depth $(\mathrm{m})$ of microbial community assemblages. The proximity of samples illustrates the similarity of microbial communities. CP: Cornucopina pectogemma; NF: Nematoflustra flagellata; MM: Myxilla (Myxilla) mollis; MT: Mycale tylotornota; RN: Rossella nuda; AJ: Anoxycalyx (Scolymastra) joubini;

Et: diethyl ether $\left(\mathrm{Et}_{2} \mathrm{O}\right)$ extract; $\mathrm{Bu}$ : butanol $(\mathrm{BuOH})$ extract; Bry: Bryozoa; Spo: sponge

orated, they always leave a residue, which may affect microorganisms or may modify the gels in the plates.

\subsection{Selective antimicrobial activity}

We have proved here that selective antimicrobial activity with differential bacterial and eukaryotic attachment occurs, even when all the microorganisms in our experiment came from the same water column, with the same environmental factors and physicochemical properties of the initial surface (maturation biofilm). Not all the extracts showed antifouling activity, but all of them resulted in different microbial communities, with a high similarity within replicates. Microbial inhibition must, therefore, be a more selective process than just a reduction in surface biofilms. Specifically, when a bacterium grows on top of another, this may either provide positive settlement cues for innocuous larvae or negative cues for potential competitors (Walls et al. 1993).
In general terms, the more polar extracts in our experiments favored a higher number of clones per OTU than the non-polar extracts, which showed a higher antimicrobial activity. This trend can be clearly observed in the Colwellia clade, which was always more abundant in the more polar extract for most species tested. Although a total inhibition of the microbial community was never found, a shift in the number of clones per OTU and/or composition of its communities always occurred. This highlights the importance of the diversity rather than the abundance of microorganisms in the formation of biofilms. Moreover, a large variability in the effect of the extracts tested on both bacteria and eukaryotic communities was detected, including the total inhibition of eukaryotic clones by the extracts from the bryozoan Cornucopina pectogemma and the sponge Mycale tylotornota. The interference in eukaryotic communities is key for avoiding macrofouling adhesion (Almeida \& Vasconcelos 2015). Chemical defenses 
are usually quite species-specific in their ecological roles, even in sponges and bryozoans from polar waters (Avila et al. 2008, Angulo-Preckler et al. 2015, Núñez-Pons \& Avila 2015, Figuerola et al. 2017), suggesting that different chemical strategies may exist to deal with repellence, allelopathy, and fouling. Further studies should chemically analyze the compounds directly responsible for these activities.

\subsection{Natural products from the studied species}

The natural products from the species studied herein are mostly unknown. Only a taurine-conjugated anthranilic acid, glassponsine, has been found in the $\mathrm{BuOH}$ extract of the hexactinellid Anoxycalyx (Scolymastra) joubini (Carbone et al. 2014; http://pubs. rsc.org/marinlit/). A moderate antifungal activity for the crude extract of $A$. joubini has been reported (Berne et al. 2016), but we only found a significant bioactivity in its $\mathrm{BuOH}$ extract. Actually, it seems to stimulate the attachment of eukaryotic organisms, but this could be due to the low abundances of organisms settled on the controls for the $\mathrm{BuOH}$ extracts, composed solely of the basidiomycota Cryptococcus sp. Some Rossella spp., including $R$. nuda, display selective cytotoxicity against human tumor cell lines and the early development of sea urchin embryos, with undescribed metabolites (Taboada \& Avila 2010, Figuerola et al. 2013b, Turk et al. 2013, Berne et al. 2016). Moreover, anti-predatory activity in the extracts of $R$. nuda and $R$. fibulata Schulze \& Kirkpatrick, 1910 has also been reported (McClintock et al. 1993, 2000, Núñez-Pons et al. 2012, Taboada et al. 2013, Núñez-Pons \& Avila 2014). The observation that one extract prevents eukaryotic attachment while another extract from the same species promotes bacterial attachment confirms that the composition of the microbial community within the biofilm is more important than the number of attached microorganisms. Interestingly, 2 species whose extracts significantly promoted an increase in the abundance of attached organisms belong to the hexactinellid sponges, and the different bioactivities of the extracts may perhaps be associated with speciesspecific life history traits.

Mycale sponges present several cytotoxic compounds (e.g. pateamine, peloruside, mycalamide; Hood et al. 2001, Singh et al. 2011). M. tylotornota Koltun, 1964, a barely studied, rare sponge only found 5 times before in the surroundings of the South Shetland Islands, represents here the first record for the Weddell Sea (see www.gbif.org/). M. tylotornota showed the highest antifouling activity, with very low levels of eukaryotic clones on the lipophilic extract, and a complete absence of eukaryotic clones on the more polar extract. This more polar extract, together with that of C. pectogemma, were the only ones able to inhibit the growth of the most abundant basidiomycota, Cryptococcus sp. Also, some Antarctic Myxilla species have shown antibacterial activity (Angulo-Preckler et al. 2018). Lipophilic extracts of M. (Myxilla) mollis inhibited growth of the green algae Pseudokirchneriella subcapitata and were active against Staphylococcus aureus (a human methicillin-resistant strain) (Berne et al. 2016). Sacristán-Soriano et al. (2017) also studied the potential antibacterial activity of a wide panel of Antarctic invertebrates in the laboratory. Four species ( 3 sponges and 1 bryozoan species) were also included in our study. In their study, no antibacterial activity was found for the sponges $R$. nuda and A. joubini, while the sponge M. mollis and the bryozoan Nematoflustra flagellata showed activity against Antarctic bacteria (Bacillus aquimaris and Paracoccus sp., respectively). Our data show that the lipophilic extract of $M$. mollis was active in decreasing the number of eukaryotic as well as bacterial clones.

Crude extracts of the bryozoans C. pectogemma and N. flagellata have also been shown to inhibit the QS indicator strains Chromobacterium violaceum CV026 and C. violaceum VIR07 in the laboratory (Figuerola et al. 2017). Antibacterial activity was detected in the lipophilic extract, while the more polar one did not show any antimicrobial activity. In addition, both bryozoans display many other chemical defensive strategies (e.g. repellence against generalist macroinvertebrate predators; Figuerola et al. 2013a, 2017), suggesting their natural products are used for a wide array of ecological roles. Some cold-water bryozoan species possess inhibitors of QS-regulated gene expression found in diverse marine bacterial strains: e.g. Flustra foliacea harbors alkaloids with antimicrobial activity (Lippert \& Iken 2003, Peters et al. 2003). In bryozoans, many alkaloids and polyketides have been found to be responsible for different ecological defensive activities, although only 1 Antarctic bryozoan species has been chemically studied so far (Lebar et al. 2007, Sharp et al. 2007). However, bryozoans show similar antifoulant activity to sponges, being a promising source of pharmacologically interesting compounds (Figuerola \& Avila 2019). 


\subsection{Microbial communities attached to the coated plates}

Symbiotic bacteria producing bioactive compounds have been obtained from a wide variety of marine organisms, such as sponges, corals, mollusks, crustaceans, bryozoans, and ascidians in different geographical areas (see Piel 2009 and references therein). However, few studies on symbiotic bacteria in Antarctic marine invertebrates have so far been done (Giudice et al. 2019, Sacristán-Soriano et al. 2020).

Some microorganisms identified here are especially resistant to the antifouling effect produced by invertebrate extracts. Here, the most resistant bacterium was Colwellia. Colwellia contains proteins, such as the chaperones DnaK and DnaJ, that allow them to adapt to different environments (Yamauchi et al. 2004). In C. maris, the DnaK gene is essential for growth and viability under diverse environmental conditions (García-Descalzo et al. 2011). Also, some of the bacteria identified here (i.e. Colwellia, Pseudoalteromonas) are able to produce lipases (Urbanek et al. 2018), enzymes that hydrolyze ester bonds in lipids, i.e. enable the bacteria to feed on lipids. Lipases may neutralize or decrease the antifouling effect of the bioactive compounds from invertebrate extracts (Prabhawathi et al. 2014). Another possible mechanism for antifouling inhibition could be marine invertebrates controlling the secondary metabolism and colonization behaviors of the microorganisms they host. As a result, the microorganisms modify their effect on their host. For example, it has been reported that Pseudoalteromonas inhibit antibiotic and pigment production by the corals they inhabit (Dobretsov et al. 2013). This has not been observed in Antarctica so far.

Some members of the Roseobacter group, such as Loktanella and Roseobacter sp., have also been described as primary colonizers of eukaryotic hosts (Michael et al. 2016). This could explain the high number of close relatives within the Gamma- and Alphaproteobacteria, both well-known psychrophiles from Antarctica, in most treatments (Figs. S3 \& S4 in the Supplement). Five different clades within Rhodobacteracea were found in almost all the treatments (except on Rosella nuda extracts), although Roseobacter was only found on $M$. mollis extracts, probably reflecting the shift from these early primary colonizers to the secondary structure community.

Eukaryotic microorganisms may also prevent the antifouling effect of marine invertebrates. Here, we identified mainly 2 types of fungi: Cryptococcus and Mrakia. The fungus Cryptococcus has a polysaccha- ride capsule, composed mainly of glucurunoxylomannan, and can form biofilms (Martinez \& Casadevall 2007). In the laboratory, forming a biofilm makes them less susceptible to environmental stresses than their planktonic counterparts (Martinez \& Casadevall 2007). The predominance of Cryptococcus in cold waters could derive from their ability to produce polysaccharides and utilize available nutrients in oligotrophic systems (Margesin \& Miteva 2011).

\section{CONCLUSION}

We cannot conclude that the invertebrates tested here are directly responsible for the observed activity, because invertebrate-associated bacteria may also play a role, and it is indeed beneficial for the host to harbor epibiotic bacteria with antifouling properties. However, it is plausible to assume that the host chemically modulates the associated microbial community to gain benefits from such interactions, although the origin of the activity remains unclear. It should also be taken into account that, in most previous studies, 'bioactivities' were not estimated at natural concentrations or under ecological conditions. Although certain species can allocate biofouling defenses in certain specific tissues (Cronin \& Hay 1996, Furrow et al. 2003, Angulo-Preckler et al. 2015), we assumed a homogeneous distribution throughout the organism for the purpose of the present the study. This in fact means that the antifouling capacity of the invertebrates may have been underestimated and could be more effective when the antifouling compounds occur concentrated in surface tissues. Even if the responsible metabolites have not yet been described, our results suggest that the bryozoan Cornucopina pectogemma and the sponge Mycale tylotornota are promising potential new sources for antifouling compounds, being able to disrupt colonization of a substrate by microscopic eukaryotes. Further studies should be devoted to fully developing the bioactive potential of these species.

Acknowledgements. Thanks are due to F. J. Cristobo, L. Núñez-Pons, and J. Moles for their support in the lab and during the Antarctic cruises, as well as to E. Ballesté for statistical input. Thanks are also due to the crew of BAE Gabriel de Castilla for their logistic support during the dives. This research was developed in the frame of ACTIQUIM-II (CTM201017415/ANT) and DISTANTCOM (CTM2013-42667/ANT) projects from the Spanish Government. C.A.P. and B.F. were recipients of FPU (AP2009-2081) and Juan de la CiervaIncorporación (IJCI-2017-31478) fellowships, respectively. 
Furthermore, genetic analyses were supported by grants CTM2010-12134-E/ANT and CTM2011-16003-E, with E.G.L. as recipient of a PTA fellowship (PTA2016-12325-I). Also, we thank the anonymous reviewers and the editor for providing very helpful comments on the manuscript. This is an AntECO (SCAR) contribution.

Compliance with Ethical Standards

Conflict of Interest: The authors declare that they have no conflict of interest.

Ethical approval: All applicable international, national, and/ or institutional guidelines for the care and use of animals were followed.

\section{LITERATURE CITED}

Almeida JR, Vasconcelos V (2015) Natural antifouling compounds: effectiveness in preventing invertebrate settlement and adhesion. Biotechnol Adv 33:343-357

Anderson MJ (2005) Permutational multivariate analysis of variance. Department of Statistics, University of Auckland

Angulo-Preckler C, Cid C, Oliva F, Avila C (2015) Antifouling activity in some benthic Antarctic invertebrates by 'in situ' experiments at Deception Island, Antarctica. Mar Environ Res 105:30-38

Angulo-Preckler C, San Miguel O, García-Aljaro C, Avila C (2018) Antibacterial defenses and palatability of shallowwater Antarctic sponges. Hydrobiologia 806:123-138

Avila C, Iken K, Fontana A, Cimino G (2000) Chemical ecology of the Antarctic nudibranch Bathydoris hodgsoni Eliot, 1907: defensive role and origin of its natural products. J Exp Mar Biol Ecol 252:27-44

Avila C, Taboada S, Núñez-Pons L (2008) Antarctic marine chemical ecology: what is next? PSZNI: Mar Ecol 29:1-71

* Berne S, Kalauz M, Lapat M, Savin L and others (2016) Screening of the Antarctic marine sponges (Porifera) as a source of bioactive compounds. Polar Biol 39:947-959

Briand JF, Pochon X, Wood SA, Bressy C and others (2018) Metabarcoding and metabolomics offer complementarity in deciphering marine eukaryotic biofouling community shifts. Biofouling 34:657-672

Buss LW (1990) Competition within and between encrusting clonal invertebrates. Trends Ecol Evol 5:352-356

Carbone M, Núñez-Pons L, Ciavatta ML, Castelluccio F, Avila C, Gavagnin M (2014) Occurrence of a taurine derivative in an Antarctic glass sponge. Nat Prod Commun 9:469-470

Cronin G, Hay ME (1996) Within-plant variation in seaweed palatability and chemical defenses: optimal defense theory versus the growth-differentiation balance hypothesis. Oecologia 105:361-368

Dang H, Lovell CR (2016) Microbial surface colonization and biofilm development in marine environments. Microbiol Mol Biol Rev 80:91-138

* Dang H, Li T, Chen M, Huang G (2008) Cross-ocean distribution of Rhodobacterales bacteria as primary surface colonizers in temperate coastal marine waters. Appl Environ Microbiol 74:52-60

Dobretsov S, Rittschof D (2020) Love at first taste: induction of larval settlement by marine microbes. Int J Mol Sci 21: 731

Dobretsov S, Dahms HU, Tsoi MY, Qian PY (2005) Chemical control of epibiosis by Hong Kong sponges: the effect of sponge extracts on micro- and macrofouling communities. Mar Ecol Prog Ser 297:119-129
Dobretsov S, Dahms HU, Harder T, Qian PY (2006) Allelochemical defense against epibiosis in the macroalga Caulerpa racemosa var. turbinata. Mar Ecol Prog Ser 318: 165-175

Dobretsov S, M Abed RM, Teplitski M (2013) Mini-review: Inhibition of biofouling by marine microorganisms. Biofouling 29:423-441

Edgar RC, Haas BJ, Clemente JC, Quince C, Knight R (2011) UCHIME improves sensitivity and speed of chimera detection. Bioinformatics 27:2194-2200

Figuerola B, Avila C (2019) The phylum Bryozoa as a promising source of anticancer drugs. Mar Drugs 17:477

*Figuerola B, Núñez-Pons L, Moles J, Avila C (2013a) Feeding repellence in Antarctic bryozoans. Naturwissenschaften 100:1069-1081

Figuerola B, Taboada S, Monleón-Getino T, Vázquez J, Avila C (2013b) Cytotoxic activity of Antarctic benthic organisms against the common sea urchin Sterechinus neumayeri. Oceanography 1:107

Figuerola B, Angulo-Preckler C, Núñez-Pons L, Moles J and others (2017) Experimental evidence of chemical defence mechanisms in Antarctic bryozoans. Mar Environ Res 129:68-75

Furrow FB, Amsler CD, McClintock JB, Baker BJ (2003) Surface sequestration of chemical feeding deterrents in the Antarctic sponge Latrunculia apicalis as an optimal defense against sea star spongivory. Mar Biol 143: 443-449

García-Descalzo L, Alcazar A, Baquero F, Cid C (2011) Identification of in vivo HSP90-interacting proteins reveals modularity of HSP90 complexes is dependent on the environment in psychrophilic bacteria. Cell Stress Chaperones 16:203-218

Giudice AL, Azzaro M, Schiaparelli S (2019) Microbial symbionts of Antarctic marine benthic invertebrates. In: CastroSowinski S (ed) The ecological role of micro-organisms in the Antarctic environment. Springer, Cham, p 277-296

Harder T, Yee LH (2009) Bacterial adhesion and marine fouling. In: Hellio C, Yebra D (eds) Advances in marine antifouling coatings and technologies. Woodhead Publishing, Cambridge, p 113-131

Henrikson AA, Pawlik JR (1995) A new antifouling assay method: results from field experiments using extracts of four marine organisms. J Exp Mar Biol Ecol 194: 157-165

Henrikson AA, Pawlik JR (1998) Seasonal variation in biofouling of gels containing extracts of marine organisms. Biofouling 12:245-255

Hood KA, West LM, Berridge MV, Miller JH (2001) Induction of apoptosis by the marine sponge (Mycale) metabolite mycalamide A and pateamine. Apoptosis 6:207-219

Kruskal JB (1964) Nonmetric multidimensional scaling: a numerical method. Psychometrika 29:115-129

Kumar S, Stecher G, Li M, Knyaz C, Tamura K (2018) MEGA $\mathrm{X}$ : Molecular Evolutionary Genetics Analysis across computing platforms. Mol Biol Evol 35:1547-1549

KLarkin MA, Blackshields G, Brown NP, Chenna R and others (2007) Clustal W and Clustal X version 2.0. Bioinformatics 23:2947-2948

* Lebar MD, Heimbegner JL, Baker BJ (2007) Cold-water marine natural products. Nat Prod Rep 24:774-797

Lema KA, Constancias F, Rice SA, Hadfield MG (2019) High bacterial diversity in nearshore and oceanic biofilms and their influence on larval settlement by Hydroides elegans (Polychaeta). Environ Microbiol 21:3472-3488 
Lippert H, Iken K (2003) Palatability and nutritional quality of marine invertebrates in a sub-Arctic fjord. J Mar Biol Assoc UK 83:1215-1219

Maki JS, Mitchell R (2002) Biofouling in the marine environment. In: Bitton G (ed) Encyclopedia of Environmental Microbiology. John Wiley \& Sons, New York, NY, p 610-619

Margesin R, Miteva V (2011) Diversity and ecology of psychrophilic microorganisms. Res Microbiol 162:346-361

* Martinez LR, Casadevall A (2007) Cryptococcus neoformans biofilm formation depends on surface support and carbon source and reduces fungal cell susceptibility to heat, cold, and UV light. Appl Environ Microbiol 73:4592-4601

McClintock JB, Slattery M, Baker BJ, Heine J (1993) Chemical ecology of Antarctic sponges from McMurdo Sound, Antarctica: ecological aspects. Antarct J US 28:134-135

McClintock JB, Baker BJ, Amsler CD, Barlow TL (2000) Chemotactic tube-foot responses of the spongivorous sea star Perknaster fuscus to organic extracts of sponges from McMurdo Sound, Antarctica. Antarct Sci 12:41-46

Michael V, Frank O, Bartling P, Scheuner C, Göker M, Brinkmann H, Petersen J (2016) Biofilm plasmids with a rhamnose operon are widely distributed determinants of the 'swim-or-stick' lifestyle in roseobacters. ISME J 10: 2498-2513

Núñez-Pons L, Avila C (2014) Defensive metabolites from Antarctic invertebrates: does energetic content interfere with feeding repellence? Mar Drugs 12:3770-3791

* Núñez-Pons L, Avila C (2015) Natural products mediating ecological interactions in Antarctic benthic communities: a mini-review of the known molecules. Nat Prod Rep 32: 1114-1130

* Núñez-Pons L, Rodríguez-Arias M, Gómez-Garreta A, Ribera-Siguán A, Avila C (2012) Feeding deterrency in Antarctic marine organisms: bioassays with the omnivore amphipod Cheirimedon femoratus. Mar Ecol Prog Ser 462:163-174

* Olejnik S, Algina J (2003) Generalized eta and omega squared statistics: measures of effect size for some common research designs. Psychol Methods 8:434-447

* Ortlepp S, Pedpradap S, Dobretsov S, Proksch P (2008) Antifouling activity of sponge-derived polybrominated diphenyl ethers and synthetic analogues. Biofouling 24: 201-208

* Patiño Cano LP, Quintana Manfredi R, Pérez M, García M and others (2018) Isolation and antifouling activity of azulene derivatives from the Antarctic gorgonian Acanthogorgia laxa. Chem Biodivers 15:e1700425

* Peters L, König GM, Wright AD, Pukall R, Stackebrandt E, Eberl L, Riedel K (2003) Secondary metabolites of Flustra foliacea and their influence on bacteria. Appl Environ Microbiol 69:3469-3475

Piel J (2009) Metabolites from symbiotic bacteria. Nat Prod Rep 26:338-362

Potvin M, Lovejoy C (2009) PCR-based diversity estimates of artificial and environmental 18S rRNA gene libraries. J Eukaryot Microbiol 56:174-181

* Prabhawathi V, Boobalan T, Sivakumar PM, Doble M (2014) Antibiofilm properties of interfacially active lipase immobilized porous polycaprolactam prepared by LB technique. PLOS ONE 9:e96152

Proksch P, Edrada R, Ebel R (2002) Drugs from the seas- current status and microbiological implications. Appl Microbiol Biotechnol 59:125-134

Qian P-Y, Lau SCK, Dahms H-U, Dobretsov S, Harder T (2007) Marine biofilms as mediators of colonization by marine macroorganisms: implications for antifouling and aquaculture. Mar Biotechnol 9:399-410

* Richmond MD, Seed R (1991) A review of marine macrofouling communities with special reference to animal fouling. Biofouling 3:151-168

Sacristán-Soriano O, Angulo-Preckler C, Vázquez J, Avila C (2017) Potential chemical defenses of Antarctic benthic organisms against marine bacteria. Polar Res 36:1390385

Sacristán-Soriano O, Pérez Criado N, Avila C (2020) Host species determines symbiotic community composition in Antarctic sponges (Porifera: Demospongiae). Front Mar Sci 7:474

Shapiro SS, Wilk MB (1965) An analysis of variance test for normality (complete samples). Biometrika 52:591-611

* Sharp JH, Winson MK, Porter JS (2007) Bryozoan metabolites: an ecological perspective. Nat Prod Rep 24:659-673

Singh AJ, Razzak M, Teesdale-Spittle P, Gaitanos TN and others (2011) Structure-activity studies of the pelorusides: new congeners and semi-synthetic analogues. Org Biomol Chem 9:4456

Slattery M, McClintock JB, Heine JN (1995) Chemical defenses in Antarctic soft corals: evidence for antifouling compounds. J Exp Mar Biol Ecol 190:61-77

Steinberg PD, De Nys R (2002) Chemical mediation of colonization of seaweed surfaces. J Phycol 38:621-629

* Taboada S, Avila C (2010) Antitumoural activity in Antarctic and sub-Antarctic benthic organisms. Antarct Sci 22: 494-507

Taboada S, Núñez-Pons L, Avila C (2013) Feeding repellence of Antarctic and sub-Antarctic benthic invertebrates against the omnivorous sea star Odontaster validus. Polar Biol 36:13-25

Toupoint N, Mohit V, Linossier I, Bourgougnon N and others (2012) Effect of biofilm age on settlement of Mytilus edulis. Biofouling 28:985-1001

* Turk T, Avguštin JA, Batista U, Strugar G and others (2013) Biological activities of ethanolic extracts from deep-sea Antarctic marine sponges. Mar Drugs 11:1126-1139

Urbanek AK, Rymowicz W, Mirończuk AM (2018) Degradation of plastics and plastic-degrading bacteria in cold marine habitats. Appl Microbiol Biotechnol 102:7669-7678

Wahl M (1997) Living attached: aufwuchs, fouling, epibiosis. In: Nagabushanam R, Thompson MF (eds) Fouling organisms of the Indian Ocean: biology and control technology. Oxford and IBH, New Delhi, p 31-83

* Walls JT, Ritz DA, Blackman AJ (1993) Fouling, surface bacteria and antibacterial agents of four bryozoan species found in Tasmania, Australia. J Exp Mar Biol Ecol 169: $1-13$

*Wiencek KM, Fletcher M (1997) Effects of substratum wettability and molecular topography on the initial adhesion of bacteria to chemically defined substrata. Biofouling 11:293-311

*Yamauchi S, Okuyama H, Nishiyama Y, Hayashi H (2004) Gene structure and transcriptional regulation of dnaK and dnaJ genes from a psychrophilic bacterium, Colwellia maris. Extremophiles 8:283-290 


\begin{tabular}{|c|c|c|c|c|c|}
\hline \multicolumn{6}{|c|}{ Appendix } \\
\hline Phylum & Class & Order & Family & Taxa & Clone \\
\hline Actinobacteria & Actinobacteria & Actinomycetales & Micrococcaceae & Arthrobacter sp. & B-14-14 \\
\hline \multirow{20}{*}{$\begin{array}{l}\text { Bacteroidetes } \\
\text { Proteobacteria }\end{array}$} & Flavobacteriia & Flavobacteriales & Flavobacteriaceae & Winogradskyella sp. & B-07-16 \\
\hline & Alphaproteobacteria & & & Alpha proteobacterium & B-01-19 \\
\hline & & Sphingomonadales & $\begin{array}{l}\text { Phyllobacteriaceae } \\
\text { Rhodobacteraceae }\end{array}$ & $\begin{array}{l}\text { Pseudahrensia sp. } \\
\text { Litoreibacter sp. } \\
\text { Loktanella sp. } \\
\text { Octadecabacter sp. } \\
\text { Roseobacter sp. } \\
\text { Thalassobius sp. } \\
\text { Sphingomonas sp. }\end{array}$ & $\begin{array}{l}\text { B-10-17 } \\
\text { B-01-17 } \\
\text { B-04-07 } \\
\text { B-07-22 } \\
\text { B-09-07 } \\
\text { B-12-08 } \\
\text { B-10-21 }\end{array}$ \\
\hline & Deltaproteobacteria & Bdellovibrionales & Bacteriovoracaceae & $\begin{array}{l}\text { Bacteriovorax sp. } \\
\text { Peredibacter sp. }\end{array}$ & $\begin{array}{l}\text { B- } 09-12 \\
\text { B- } 04-03\end{array}$ \\
\hline & Gammaproteobacteria & & & & \\
\hline & & Alteromonadales & Alteromonadacea & $\begin{array}{l}\text { Gamma proteobacterium } \\
\text { Alteromonas sp. } \\
\text { Glaciecola sp. }\end{array}$ & $\begin{array}{l}\text { B-02-04 } \\
\text { B-01-04 } \\
\text { B-01-02 }\end{array}$ \\
\hline & & & Colwelliaceae & $\begin{array}{l}\text { Colwellia sp. } \\
\text { Thalassomonas sp. }\end{array}$ & $\begin{array}{l}\text { B-01-08 } \\
\text { B-05-01 }\end{array}$ \\
\hline & & & Moritellaceae & Moritella sp. & B- $02-10$ \\
\hline & & & $\begin{array}{l}\text { Pseudoalteromona- } \\
\text { daceae }\end{array}$ & Pseudoalteromonas sp. & B-01-03 \\
\hline & & & Psychromonadaceae & Psychromonas sp. & B-09-03 \\
\hline & & Cellvibrionales & Cellvibrionaceae & $\begin{array}{l}\text { Pseudomaricurvus sp. } \\
\text { Pseudoteredinibacter sp. }\end{array}$ & $\begin{array}{l}\text { B- } 08-15 \\
\text { B-12-10 }\end{array}$ \\
\hline & & & Halieaceae & Haliea sp. & B- $04-15$ \\
\hline & & & Spongiibacteraceae & Dasania sp. & B- $05-19$ \\
\hline & & & & Spongiibacter sp. & B-15-14 \\
\hline & & Oceanospirillales & Oceanospirillaceae & Marinomonas sp. & B-07-06 \\
\hline & & & & Neptunomonas sp. & B-09-01 \\
\hline & & & & Oleispira sp. & B-04-11 \\
\hline & & & Saccharospirillaceae & Reinekea sp. & B-01-15 \\
\hline & & Thiotrichales & Piscirickettsiaceae & Piscirickettsiaceae bacterium & B-15-09 \\
\hline & & Vibrionales & Vibrionaceae & Vibrionaceae bacterium & B-13-11 \\
\hline
\end{tabular}

Table A2. Taxonomical classification of the eukaryotic clones sequenced in this study

\begin{tabular}{|llllll|}
\hline Phylum & Class & Order & Family & Taxa & Clone \\
\hline Basidiomycota & Tremellomycetes & & & Agaricomycotina & E-15-01 \\
& & Tremellales & Cuniculitremaceae & Kockovaella sp. & E-01-01 \\
& & Cystofilobasidiales & Mrakiaceae & Mrakia sp. & E-02-01 \\
& & & & Cercozoa & E-08-09 \\
Cercozoa & & Thaumatomonadida & Allas sp. & E-06-08 \\
& Imbricatea & & & Chlorophyta & E-01-22 \\
Chlorophyta & & Suessiales & Symbiodiniaceae & Symbiodinium sp. & E-06-15 \\
Dinoflagellata & Dinophyceae & Ochromonadales & Ochromonadaceae & Ochromonadaceae & E-08-05 \\
Ochrophyta & Chrysophyceae & & & & \\
\hline
\end{tabular}

Editorial responsibility: Rutger de Wit, Montpellier, France
Submitted: October 23, 2019; Accepted: August 17, 2020 Proofs received from author(s): November 18, 2020 